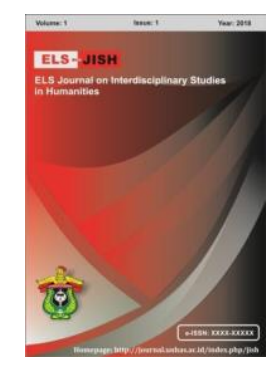

ELS-JISH

ELS Journal on Interdisciplinary Studies on Humanities

Volume 3 Issue 1, 2020

ISSN (print) : 2621-0843

ISSN (online) : 2621-0835

Homepage : http://journal.unhas.ac.id/index.php/jish

\title{
A Voyage to Lilliput of Gulliver's Travel: Environmental Hedonism
}

\author{
Arin Mantara Anggawirya ${ }^{1}$, Lastika Ary Prihandoko ${ }^{2}$ \\ 1arindanggawirya@gmai.com
}

\begin{abstract}
This paper analyzes the notion of environment pictured in Gulliver's Travel: A Voyage to Lilliput by Jonathan Swift in 1762. In analyzing the environment, the writers related some issues in this novel to the concept of eco-cosmopolitan society by $P$. Marland, and elaborating the issues of environment in this novel through the concept of ecocriticism by L. Buell. Through Gulliver's travel: a Voyage to Lilliput, the notions of Plague, Economical Crisis, Famine and Environmental hedonism were pictured. Lilliput society that living with Gulliver rise another perspective on seeing the environment, which gives the illustration on how these small creatures adapt to sustain Gulliver as a giant.
\end{abstract}

Keywords: conflict, face, qualitative, face loss, pragmatics.

How to cite: Anggawirya, A. M., \& Prihandoko, A. L. (2020). A Voyage to Lilliput of Gullver's Travel: Environmental Hedonism. ELS Journal on Interdisciplinary Studies in Humanities, 3(1), 110-121. DOI: http://dx.doi.org/10.34050/els-jish.v3i1.9529

\section{Introduction}

Dobrogoszcz (2017) wrote the planet heals itself: The overkill of Homo sapiens in contemporary literature. Dobrogoszcz analyzed some literary works such as Oryx and Crake by Margaret Atwood (2003), Cloud Atlas by David Mitchell (2004), The Road by Cormac McCarthy (2006) and Stone Gods by Jeanette Winterson (2007). This study reveals that the current overflow of population damage both the earth and humanity. Each of the novels presents some form of a post-apocalyptic and can be generalized in term of the overflow of the human race.

Another writer, Wright (2017) wrote Comedy and Madness in Swift: The Idiosyncrasies of Lemuel Gulliver. By using the theory of comedy, humor, and affect, Wright revealed the psychology of Gulliver as the main character in the novel Gulliver's Travel. Gulliver in Wright research was revealed as a caricature; an exaggeration of an English colonizer. Moreover, Gulliver is the spokesperson of the writer, Jonathan Swift, shown as a light-hearted, and joyful.

In the same year, David (2017) conducted a research Swift and Satire: Gulliver's Travel and the Age of Reason. This research revealed a historical

${ }^{1,2}$ Universitas Musamus, Indonesia. 
exploration this historical exploration includes some points In which related to the verification of whether this Gulliver's Travel, is valid or stems for a misunderstanding of a new scientific concept. Another aspect, which is the concern in this part, was also the political context since Swift's view was more political.

Although Dobrogoszcz (2017) had conducted similar research, which related the Gulliver's Travel to the nowadays world, he did not investigate the relationship toward the Earth and environment. The gap that arises between this research and Wright (2017) is the research did not only focus on the character as the prior thing to be analyzed, but also the value of the environmentalist movement, which is illustrated in the sequence of events in the novel.

This paper adapts an ecocriticism approach by Lawrance Buell (1996) and closely reads Gulliver's Travel: A Voyage to Lilliput to argue some issues of the Eco-cosmopolitan society that proposed by P. Marland (2013) specifically in terms of plague, economic crisis and environmental hedonism in this satire. Shortly, this study define the Ecocriticism as an umbrella term for a range of critical approaches that explore the representation in literature (and other cultural forms) of the relationship between the human and the nonhuman, largely from the perspective of anxieties around humanity's destructive impact on the biosphere (Marland, 2013). Moreover, Eco cosmopolitan society is defined as a development, which 'recognizes ethnic and national particularities and yet transcends ethnic and national boundaries,' exploring 'all facets of human experience from an environmental viewpoint' (Scott, 2012:6-7). In elaborating those concepts, the writers analyzes some issues found in the interaction of the Lilliput and Gulliver, and

in Buell (1996), searching the literary texts that conveyed the environmental message. In search of the literary text, he made some characterization of the works, which can convey the message of the environment. According to Buell, (1996);

a. The nonhuman environment is present not merely as a framing device but as a presence that begins to suggest that human history is implicated in natural history

b. The human interest is not understood to be the only legitimate interest

c. Human accountability to the environment is part of the text's ethical orientation.

d. Some sense of the environment as a process rather than as a constant or a given is at least implicit in the text

Those criteria were used for the researcher all around the world in determining the literary work, which conveyed the earth, massage. The world tends to be the target of this literary work that is the concern on the ecocriticism. It can be conducted through the process of using literary work as the medium to educate and imply the value of the earth itself. Another idea is to reinforce the activism of society in saving the life of the earth through literary work. 
The term of Eco-cosmopolitan emerged in 2009, which was indicated by the acceptance of the ethnic and national particularities that generates human experience from an environmental viewpoint (Scott, 2012). In her statement;

To envision how ecologically based advocacy on behalf of the non-human world as well as on behalf of greater socio-environmental justice might be formulated in terms that are premised no longer as primarily on ties to local places but on ties to territories and systems that are understood to encompass the planet as a whole

This idea strongly emphasizes that the ecological movement need to consider the planet as a whole. The term of "Right Mother Earth" which was recognized in 2010 at 'World Peoples' Conference on Climate Change in Cochabamba, Bolivia, indicates that the movement of the ecological perspective in saving the earth are started globally

All part of Mother Earth, an indivisible, living community of interrelated and interdependent beings with a common destiny

The Right of Mother Earth above strongly demand world citizenship to gather and save the earth as a living community. In literature, this could be analyzed through the relation of human and non-human interaction. That interaction indicates the value of how the movement of saving the mother earth should be conducted through the literature.

The impact of industrial improvement is undeniable in several aspects, also in the environment that becomes the victim. John O'Neil (2008) stated:

Living in a world confronted by mounting environmental problems, reading the increasing global deforestation and desertification, loss of species diversity, pollution and global warming. In everyday life, people mourn the loss of valued landscapes and urban spaces. Underlying these problems are conflicting priorities and values. Yet dominant approaches to policy making seem ill equipped to capture the various ways in which the environment matters to us

People are living with the many problems of the environment. They might still consider that this still a small problem, but many pieces of research had proven that this earth is in danger; NASA in 2007 released an article that signifies the Earth's climate is in a dangerous point. Therefore, the government is struggling in making a suit policy for people to live with. This policy is made based on the consideration of living on a feasible planet in the future.

In the middle of the 2017, Paris Agreement becomes the idea of the people in saving the Mother Earth, despite the problem of US that leaves the agreement since they believed that they are the one who suspected and considered as the country that had the highest emission in this earth, the effort of saving the mother earth continued.

In a literary campaign, many writers tried to emphasize the value of the environment toward their work, Silent Spring is remarkable work. It describes the bitterness of nature, which represent the missing of beauty in nature. Much other noticeable works in literature also can be classified as the campaign of the 
environment in saving the Mother Earth, The Road not Taken by Robert Frost, Gulliver's Travel by Jonathan Swift,

Otherwise, On the hedonist conception, welfare or happiness consists in pleasure and the absence of pain (O'Neill et al., 2008). Some aspects might indicate the pleasure or pain; Intensity, Duration, Certainty or uncertainty, propinquity or remoteness. Those are the circumstance in considering the pleasure or pain.

In contemporary behavioral and social sciences, the term hedonic wellbeing is used less frequently. A reason for this is that hedonism as a theoretical (data-free) concept is confusing to quantify (Baselmans \& Bartels, 2018).

In the moral philosophical context, hedonism denotes that the good should be pleasurable life. A novelist Aldous Huxley in 1932 argued that this hedonism could be bad for both the individual and the environment. In an environment perspective, hedonism gives rise to over-consumption of natural resource (Veenhoven, 2003).

Another concept in hedonism is at the individual level. As an example, hedonism undermines health. Consuming drugs, alcohol, and tobacco, might give the consumer pleasure at that moment, but in the long term, it will affect badly.

This long-term idea can be conceptualized as the impact of the current circumstance of the environment nowadays. Greediness of human in exploiting the resource harms the environment itself. Moreover, without any solution given toward this problem, it will affect making the earth as not a possible place to live anymore

\section{Method}

Method used in this research is descriptive qualitative. Data was collected from the novel of gulliver's travel by jonathan swift. After the data collected, the researcher classify the data based on the issue of the environment portrayed in the novel and the issue of hedonism. the data that had been classified, then analyzed using the concept of Eco-cosmopolitan Society.

\section{Result}

In classifying the data, writers use certain codes as follow:

$$
\begin{array}{ll}
\text { GT } & =\text { Gulliver Travel } \\
\mathrm{H} & =\text { Hedonism Acts } \\
\mathrm{E} & =\text { Environment (pictured in the novel) } \\
\mathrm{P} & =\text { Pages ... }
\end{array}
$$

Table below provides the readers the data taken originally from the story of Gulliver travel: A voyage to Lilliput, which related to the criteria of environment that being represented in Gulliver's Travel 
Table 1. Environment Pictured in Gulliver's Travel: A Voyage to Lilliput

No. Data

Data
Code

Quotation

Sources

I lay down on the grass, which was very short and soft, where I

1. GT-E///001 slept sounder than ever I remembered to have done in my life, and, as I reckoned, about nine hours; for when I awaked, it was just day-light

At the place where the carriage stopped there stood an ancient temple, esteemed to be the largest in the whole kingdom; which,

2. GT-E/I/002 having been polluted some years before by an unnatural murder, was, according to the zeal of those people, looked upon as profane, and therefore had been applied to common use, and all the ornaments and furniture carried away The country around appeared like a continued garden, and the enclosed fields, which were generally forty feet square, resembled

3. GT- so many beds of flowers. These fields were intermingled with $\mathrm{E} / \mathrm{Il} / 003$ woods of half a stang, $\{1\}$ and the tallest trees, as I could judge, appeared to be seven feet high. I viewed the town on my left hand, which looked like the painted scene of a city in a theatre As the common size of the natives is somewhat under six inches high, so there is an exact proportion in all other animals, as well as plants and trees: for instance, the tallest horses and oxen are

4. GT- between four and five inches in height, the sheep an inch and half, more or less: their geese about the bigness of a sparrow, and so the several gradations downwards till you come to the smallest, which to my sight, were almost invisible; but nature has adapted the eyes of the Lilliputians to all objects proper for their view: they see with great exactness, but at no great distance

5. GT- Their tallest trees are about seven feet high: I mean some of those

5. E/IV/005 in the great royal park, the tops whereof I could but just reach with my fist clenched

6. GT- The other vegetables are in the same proportion; but this I leave to $\mathrm{E} / \mathrm{IV} / 006$ the reader's imagination

They bury their dead with their heads directly downward, because

7. GT- they hold an opinion, that in eleven thousand moons they are all to rise again; in which period the earth (which they conceive to be
flat) will turn upside down, and by this means they shall, at their resurrection, be found ready standing on their feet The cottagers and labourers keep their children at home, their

8. GT- business being only to till and cultivate the earth, and therefore and diseased among them, are supported by hospitals; for begging is a trade unknown in this empire

This following table will show the readers the data, which were classified as the data that represented the hedonism act toward the environment, 
Table 2. Hedonism acts pictured in Gulliver's Travel: A Voyage to Lilliput

\begin{tabular}{|c|c|c|c|}
\hline No. & $\begin{array}{l}\text { Data } \\
\text { Code }\end{array}$ & Quotation & Sources \\
\hline 1. & $\begin{array}{l}\text { GT- } \\
\mathrm{H} / / / 001\end{array}$ & $\begin{array}{l}\text { when in an instant I felt above a hundred arrows discharged } \\
\text { on my left hand, which, pricked me like so many needles; }\end{array}$ & P.15 \\
\hline 2. & $\begin{array}{l}\text { GT- } \\
\mathrm{H} / \mathrm{l} / 002\end{array}$ & $\begin{array}{l}\text { He descended from the stage, and commanded that several } \\
\text { ladders should be applied to my sides, on which above a } \\
\text { hundred of the inhabitants mounted and walked towards my } \\
\text { mouth, laden with baskets full of meat, which had been } \\
\text { provided and sent thither by the king's orders, upon the first } \\
\text { intelligence he received of me. }\end{array}$ & P.17 \\
\hline 3. & $\begin{array}{l}\text { GT- } \\
\text { H/l/003 }\end{array}$ & $\begin{array}{l}\text { and being a most ingenious people, they slung up, with } \\
\text { great dexterity, one of their largest hogsheads, then rolled it } \\
\text { towards my hand, and beat out the top }\end{array}$ & P.18 \\
\hline 4. & $\begin{array}{l}\text { GT- } \\
\mathrm{H} / / / 004\end{array}$ & $\begin{array}{l}\text { Five hundred carpenters and engineers were immediately } \\
\text { set at work to prepare the greatest engine they had }\end{array}$ & P.21 \\
\hline 5. & $\begin{array}{l}\text { GT- } \\
\text { H///005 }\end{array}$ & $\begin{array}{l}\text { It was a frame of wood raised three inches from the ground, } \\
\text { about seven feet long, and four wide, moving upon } \\
\text { twentytwo wheels }\end{array}$ & P.21 \\
\hline 6. & $\begin{array}{l}\text { GT- } \\
\mathrm{H} / / / 006\end{array}$ & $\begin{array}{l}\text { Eighty poles, each of one foot high, were erected for this } \\
\text { purpose, and very strong cords, of the bigness of } \\
\text { packthread, were fastened by hooks to many bandages, } \\
\text { which the workmen had girt round my neck, my hands, my } \\
\text { body, and my legs }\end{array}$ & P.21 \\
\hline 7. & $\begin{array}{l}\text { GT- } \\
\mathrm{H} / / / 007\end{array}$ & $\begin{array}{l}\text { Nine hundred of the strongest men were employed to draw } \\
\text { up these cords, by many pulleys fastened on the poles }\end{array}$ & P.21 \\
\hline 8. & $\begin{array}{l}\text { GT- } \\
\text { H///008 }\end{array}$ & $\begin{array}{l}\text { Fifteen hundred of the emperor's largest horses, each about } \\
\text { four inches and a half high, were employed to draw me } \\
\text { towards the metropolis }\end{array}$ & P.22 \\
\hline 9. & $\begin{array}{l}\text { GT- } \\
\text { H/l/009 }\end{array}$ & $\begin{array}{l}\text { We made a long march the remaining part of the day, and, } \\
\text { rested at night with five hundred guards on each side of me, } \\
\text { half with torches, and half with bows and arrows, ready to } \\
\text { shoot me if I should offer to stir }\end{array}$ & P.22 \\
\hline 10. & $\begin{array}{l}\text { GT- } \\
\text { H/II/010 }\end{array}$ & $\begin{array}{l}\text { I took these vehicles and soon emptied them all; twenty of } \\
\text { them were filled with meat, and ten with liquor }\end{array}$ & P.26-27 \\
\hline 11. & $\begin{array}{l}\text { GT- } \\
\text { H/II/011 }\end{array}$ & $\begin{array}{l}\text { during which time, the emperor gave orders to have a bed } \\
\text { prepared for me. Six hundred beds of the common measure } \\
\text { were brought in carriages, and worked up in my house; a } \\
\text { hundred and fifty of their beds, sewn together, made up the } \\
\text { breadth and length; and these were four double: which, } \\
\text { however, kept me but very indifferently from the hardness of } \\
\text { the floor, that was of smooth stone. By the same } \\
\text { computation, they provided me with sheets, blankets, and } \\
\text { coverlets, tolerable enough for one who had been so long } \\
\text { inured to hardships }\end{array}$ & P.29 \\
\hline
\end{tabular}


In the midst of these consultations, several officers of the army went to the door of the great council-chamber, and two of them being admitted, gave an account of my behaviour to the six criminals above-mentioned; which made so favourable an impression in the breast of his majesty and the whole board, in my behalf, that an imperial commission was issued out, obliging all the villages, nine hundred yards GT- round the city, to deliver in every morning six beeves, forty sheep, and other victuals for my sustenance; together with a proportionable quantity of bread, and wine, and other liquors; for the due payment of which, his majesty gave assignments upon his treasury:- for this prince lives chiefly upon his own demesnes; seldom, except upon great occasions, raising any subsidies upon his subjects, who are bound to attend him in his wars at their own expense An establishment was also made of six hundred persons to

13. GT be my domestics, who had board-wages allowed for their $\mathrm{H} / \mathrm{II} / 013$ maintenance, and tents built for them very conveniently on each side of my door

GT- It was likewise ordered, that three hundred tailors should $\mathrm{H} / \mathrm{II} / 014$ make me a suit of clothes, after the fashion of the country

I spent in cutting down with my knife some of the largest

15. GT trees in the royal park, about a hundred yards distant from $\mathrm{H} / \mathrm{IV} / 015$ the city. Of these trees, I made two stools, each about three feet high, and strong enough to bear my weight Two hundred sempstresses were employed to make me

16. GTshirts, and linen for my bed and table, all of the strongest and coarsest kind they could get; which, however, they were forced to quilt together in several folds, for the thickest was some degrees finer than lawn

17. GTThree hundred tailors were employed in the same manner to make me clothes; but they had another contrivance for taking my measure

18. $\mathrm{GT} / \mathrm{VI} / 018$

I had three hundred cooks to dress my victuals, in little $\mathrm{H} / \mathrm{VI} / 018$ convenient huts built about my house, where they

GT- I got dry to the boat, and by the assistance of two thousand

19. $\mathrm{H} / \mathrm{VIII} / 01$ men, with ropes and engines, I made a shift to turn it on its 9 bottom, and found it was but little damaged

Five hundred workmen were employed to make two sails to

GTmy boat, according to my directions, by quilting thirteen folds

20. $\mathrm{H} / \mathrm{VIII} / 02$ 0

GT-

21. $\mathrm{H} / \mathrm{VIII} / 02$ 1 of their strongest linen together. I was at the pains of making ropes and cables, by twisting ten, twenty, or thirty of the thickest and strongest of theirs His majesty presented me with fifty purses of two hundred sprugs a-piece, together with his picture at full length, which I put immediately into one of my gloves, to keep it from being hurt 
Arin Mantara Anggawirya. 3(1): 110-121

\begin{tabular}{llll}
\hline GT- & I stored the boat with the carcases of a hundred oxen, and & \\
22. & H/VIII/02 & $\begin{array}{l}\text { three hundred sheep, with bread and drink proportionable, } \\
\text { and as much meat ready dressed as four hundred cooks } \\
\text { could provide }\end{array}$ & P.92 \\
\hline
\end{tabular}

\section{Discussion}

In analyzing the data of environment found in this research, writers used the concept of Environmental Imagination by Lawrence Buell. These are the characteristics of environment used in this research:

Table 3. Swift's Gulliver Travel in Buell's Concept of Ecocriticism

\begin{tabular}{|c|c|c|}
\hline No. & Characteristics & References \\
\hline 1. & $\begin{array}{l}\text { The nonhuman environment is present not merely as a framing } \\
\text { device but as a presence that begins to suggest that human } \\
\text { history is implicated in natural history }\end{array}$ & $\begin{array}{l}\text { GT-E/I/002, } \\
\text { GT-E/II/003 }\end{array}$ \\
\hline 2. & $\begin{array}{l}\text { The human interest is not understood to be the only legitimate } \\
\text { interest }\end{array}$ & $\begin{array}{l}\text { GT- } \\
\text { E/IV/007, } \\
\text { GT- } \\
\text { E/IV/008 } \\
\text { GT- }\end{array}$ \\
\hline 3. & $\begin{array}{l}\text { Human accountability to the environment is part of the text's } \\
\text { ethical orientation. }\end{array}$ & $\begin{array}{l}\text { E/IV/007, } \\
\text { GT- } \\
\text { E/IV/008 }\end{array}$ \\
\hline 4. & $\begin{array}{l}\text { Some sense of the environment as a process rather than as a } \\
\text { constant or a given is at least implicit in the text }\end{array}$ & $\begin{array}{l}\text { GT-E/I/001, } \\
\text { GT-E/I/002, } \\
\text { GT-E/II/003 }\end{array}$ \\
\hline
\end{tabular}

As the data above has proven that this chapter of Gulliver's Travel was loaded with some values of the green literary works, the writers then related some of the issues of hedonism act to some concept that being the concern of the eco-cosmopolitan society. Some of them are famine, plague, and economic crisis that being pictured.

\subsection{Famine}

At the beginning, it may appropriate for the Lilliputians to show their military defiance by utilizing some of the resource that they got as illustrated in GT-H/I/001, even the impact was not that much to Gulliver since he was a giant in their perspective.

Lilliputians may cost a lot to serve their guest. Even he was treated as an enemy, but due to the benefit that can be derived from Gulliver, Lilliputians started to grow some interests in living with Gulliver. In maintaining to live with the Gulliver of course much of resources need to be spent. It is also acknowledged in the novel's narration below:

They apprehended my breaking loose; that my diet would be very expensive, and might cause a famine (p. 30)

If Gulliver still stay in this land, it may cause famine toward all of the Lilliputians, since they need to spend the food resources as illustrated on GT$\mathrm{H} / \mathrm{I} / 002$, GT-H/I/003, GT-H/II/012. GT-H/II/011. That narration on the novel actually showed how the Lilliputians have the awareness of Eco-cosmopolitan 
society, rather than having a giant living with them, they prefer to maintain the balance of the food availability in their land.

Larsson (2012) defines this situation related to the issue of cosmopolitanism as follow:

The current 'Cosmo political condition' is shaped by global risks that are at once ecological, economic and social. The threats of global warming, terror and wars; the tragedies of poverty, famine, and natural disasters; and issues of human rights are no longer happening 'out there'

In this case, Lilliput's awareness was arose due to the risk that may happen. The writers were agree to Larsson, the sequence of the Gulliver's Travel showed the risk of the environment that can be damaged, from one chapter to another chapter, Gulliver and Lilliput kept showing that how both are interacted based on the risk that may be arose if they keep living together.

Moreover, it was not only on the natural resources that need to be spent, human resources also become the concern since in serving Gulliver, it could not be done by one Lilliputian including dress, or workmen that need to be mustered. As illustrated in GT-H/I/004, GT-H/I/007, GT-H/II/013, GT-H/II/014, GT-H/VI/016, GT-H/VI/017, GT-H/VIII/019, GT-H/VIII/020, it might cost half of the kingdom to work along with the Gulliver that may lead to the loss of labors that need to maintain agricultural industry in their land.

\subsection{Plague}

Another narration which indicates that this society, is a concept ecocosmopolitan society, is they considered how the impact of a sanction that might be given to Gulliver.

But again they considered, that the stench of so large a carcass might produce a plague in the metropolis, and probably spread through the whole kingdom (p. 30)

It is clearly indicated how this society consider the long-term impact especially for their environment rather than just having an instant punishment to Gulliver. As Clark (2011) in his book stated that The 'environment', after all, is, ultimately, 'everything', Lilliputians were the creature who concern on what might damage their environment, therefore the policy making was based on how it will affect toward the Kingdom.

In an article of "Man-Mountain" that referred to Gulliver's Act, Lilliput were strongly demand a clean environment by cursing Gulliver's act on extinguishing the fire with his urine

\section{ARTICLE I}

Whereas, by a statute made in the reign of his imperial majesty Calin Deffar Plune, it is enacted, that, whoever shall make water within the precincts of the royal palace, shall be liable to the pains and penalties of high-treason; notwithstanding, the said Quinbus Flestrin, in open breach of thesaid law, under colour of extinguishing the fire kindled in the apartment of his majesty's most dear imperial consort, did maliciously, traitorously, and devilishly, by discharge of his urine, put out the said fire kindled in the said apartment, lying and being within the precincts of the said royal palace, against the statute in that case provided, etc. against the duty, etc. (p. 79) 
Furthermore, they limit the Gulliver on observing their kingdom due to the size of Gulliver; even the trust had already been given to him but the in maintaining the kingdom environment;

He first request I made, after I had obtained my liberty, was, that I might have license to see Mildendo, the metropolis; which the emperor easily granted me, but with a special charge to do no hurt either to the inhabitants or their house

Lilliput Society had proven to prevent any of the threat that might cause plague spread to the Mildendo by making the policy that limit and an intention to punish Gulliver for the action that might cause plague. This policy was made based on a green consideration since even the benefit was there, but Lilliput did not tolerate even a small thing that might hurt their environment.

\subsection{Economic Crisis}

At the end of the story, Gulliver had to leave the kingdom since it was not possible for him to live with the Lilliputian. How the Lilliputians manage to discover this and making a policy to dismiss Gulliver is indicated in narration below

He represented to the emperor 'the low condition of his treasury; that he was forced to take up money at a great discount; that exchequer bills would not circulate under nine per cent. below par; that I had cost his majesty above a million and a half of sprugs' (their greatest gold coin, about the bigness of a spangle) 'and, upon the whole, that it would be advisable in the emperor to take the first fair occasion of dismissing me.' (p.74)

The treasurer was of the same opinion: he showed to what straits his majesty's revenue was reduced, by the charge of maintaining you, which would soon grow insupportable (p.82)

After all, that environmental hedonism conducted by Lilliputian might signal how the concept of eco cosmopolitan is portrayed in this satire. As Ursula in P. Chris (2016) argued The urgency of developing an ideal of "ecocosmopolitanism," or environmental world citizenship. How Lilliputians solving the hedonism and promoting the concept of eco cosmopolitan society were what the world are demanding now. Gulliver might represented as the fast growth of the technology and living society, therefore living as the Lilliputians and considering what is the best in managing the Gulliver that we had is the most efficient way in saving the mother earth.

What people are suffering now is due to the globalization affect that not directly only related to the environment, but it is more on how the interaction of individual in the earth are needed to be strengthened in realizing the 'Health Mother-Earth'. Lilliput had portrayed the prevention action \, even after they committed 'hedonism act' on the environment, they manage to not take all the benefit but rather securing the nature for future.

The earth is suffering due to the lack of solving or preventing the hedonism act that require pleasures more than considering the future, Demian (2019) in his article stated:

Today, the $\mathrm{CO} 2$ level is the highest it has been for several million years. Back then, temperatures were 3-4C hotter, sea level was 15-20 metres higher and trees grew 
at the south pole. Worse, billions of tonnes of carbon pollution continues to pour into the air every year and at a rate 10 times faster than for $66 \mathrm{~m}$ years.

What the earth needed now is the awareness of the society that have been prioritizing their own pleasure. Everyone demands pleasure in order to entertain themselves, but Gulliver's act on seeing how the Lilliput struggling to sustain in living with him had risen the awareness that to live with the Lilliput means that pushing them to spent more on their own natural resource. This case also happen today, as the Gulliver, people are demanding too much from the Lilliput as the Earth which had been serving us for a long time. This argument is strengthened by Le Page in his article (2019) stated:

The main reason is simple. Our expanding farms and cities are leaving less room for wildlife. The other major causes are the direct exploitation of wildlife such as hunting, climate change, pollution and the spread of invasive species. Climate change is set to become ever more destructive.

In seeking pleasures, the tendency of human in exploiting the nature is unavoidable. What hedonism has impacted toward the Mother-Earth today has exceeded what was being predicted. Even the best scenario in saving the earth is only by reducing a small number of temperatures. Gulliver's Travel teaches us on how even the benefit can be derived from living together might be abundant, such as having an unbeatable army for the kingdom, having a giant tool that will be useful in reducing the workmen's job, but Lilliput understood that in maintaining Gulliver was a big loss toward the nature, since they will lose many resources.

\section{Conclusion}

In this research, investigation on the Environmental Hedonism and Ecocosmopolitan discovers that there are 8 notions of the environment appeared in this novel and fulfilled the characteristics given by Lawrance Buell as one of the Green Literary work. The notions portrayed in Gulliver's Travel mostly concern on Eco-cosmopolitan were; Famine, Plague, and Economical crisis. Gulliver's Travel also portrayed 22 events that signal the concept of environmental hedonism and how to solve and minimizing the hedonism that imply the value of eco-cosmopolitan society.

\section{References}

Baselmans, B. M. L., \& Bartels, M. (2018). A genetic perspective on the relationship between eudaimonic -and hedonic well-being. Scientific Reports, 8(1), 1-10. https://doi.org/10.1038/s41598-018-32638-1

Buell, L. (1996). The Environmental Imagination: Thoreau, Nature Writing, and the Formation of American Culture. Nineteenth-Century Literature. https://doi.org/10.1525/ncl.1996.50.4.99p0192g

Clark, T. (2011). The Cambridge Introduction to Literature and the Environment. Cambridge. Cambridge University Press.

Corina, M. D. (2017). Swift and Satire: Gulliver's Travel and the Age of Reason. Annales Universitatis Apulensis, Series Philologica, 2(18/2017), 182-186.

Damian, C. (2019). Why the Guardian is putting global CO2 levels in the 
weather forecast. The Guardian. Retrieved from https://www.theguardian.com/environment/2019/apr/05/why-the-guardianis-putting-global-co2-levels-in-the-weather-forecast

Dobrogoszcz, T. (2017). The planet heals itself: The overkill of Homo sapiens in contemporary literature. European Management Journal, 35(6), 722-728. https://doi.org/10.1016/j.emj.2017.07.007

Larsson, B. (2012). The Cosmopolitanization of Childhood: Eco-Knowledge in Children's Eco-Edutainment Books. Young, 20(2), 199-218. https://doi.org/10.1177/110330881202000205

Le Page, M. (2019). Destruction of nature is as big a threat to humanity as climate change. New Scientist. Retrieved from https://www.newscientist.com/article/2201697-destruction-of-nature-is-asbig-a-threat-to-humanity-as-climate-change/

Marland, P. (2013). Ecocriticism. Literature Compass, 10(11), 846-868. https://doi.org/10.1111/lic3.12105

O’Neill, J., Holland, A., \& Light, A. (2008). Environmental Values, (Vol. 8). https://doi.org/10.3197/096327108X303882

Pak, C. (2016). Edging Towards an Eco-cosmopolitan Vision. Liverpool University Press.

Scott, S. (2012). Interdisciplinary Studies in Literature and Environment. Interdisciplinary Studies in Literature and Environment.

Veenhoven, R. (2003). Hedonism and Happiness. Journal of Happiness Studies, 4(4), 437-457.

https://doi.org/10.1023/B:JOHS.0000005719.56211.fd

Wright, E. (2017). Comedy and Madness in Swift: The Idiosyncrasies of Lemuel Gulliver. Postgraduate English, (14), 1-25. 